\title{
Hubungan masalah perilaku internalisasi dan eksternalisasi dengan tingkat kecerdasan pada remaja di kota bandung
}

\author{
Eka Fauziyya Zulnida', Lenny Kendhawati ${ }^{2}$, Marisa Fransiska Moeliono ${ }^{3}$
}

Fakultas Psikologi, Universitas Padjadjaran, Indonesia

\begin{tabular}{l}
\hline Info Artikel \\
\hline Sejarah Artikel: \\
Diterima \\
30 Juni 2020 \\
Direview \\
26 Juli 2020 \\
Disetujui \\
27 Juli 2020 \\
Dipublikasikan \\
28 September 2020 \\
\hline Keywords: adolescent, \\
internalizing behavior, \\
externalizing behavior, intelligence, \\
behavior problem
\end{tabular}

\begin{abstract}
Abstrak
Abstrak. Masa remaja merupakan masa transisi. Banyak perubahanperubahan pada individu baik secara biologis, kognitif, emosi, dan sosial. Perubahan-perubahan yang terjadi membuat remaja rentan mengalami masalah-masalah perilaku seperti perilaku internalisasi dan eksternalisasi. Tujuan penelitian ini adalah menemukan hubungan antara masalah perilaku internalisasi dan perilaku eksternalisasi dengan tingkat kecerdasan pada remaja. Subjek penelitian berjumlah 150 remaja berusia 13 - 18 tahun di Kota Bandung. Data dikumpulkan menggunakan Child Behavior Checklist $(\mathrm{CBCL})$ dan Standard Progressive Matrices (SPM). Hasil penelitian menunjukkan masalah perilaku internalisasi berkorelasi negatif dengan kecerdasan $(r=0.169, p=0.01)$, yang berarti remaja dengan tingkat kecerdasan tinggi, ditemukan sedikit menunjukkan masalah perilaku internalisasi. Sebaliknya, remaja dengan tingkat kecerdasan rendah, ditemukan banyak menunjukkan masalah perilaku internalisasi. Masalah perilaku eksternalisasi remaja tidak memiliki hubungan dengan tingkat kecerdasannya.
\end{abstract}

\section{Relation between Internalizing and Externalizing Behavior Problems with Intelligence of Adolescents in Bandung}

\begin{abstract}
Adolescent is a transition period that involves many changes in individuals both biologically, cognitively, emotionally, and socially. The changes that occur make adolescents vulnerable to behavioral problems such as internalizing and externalizing behavior. The purpose of this study is to find the relation between internalizing and externalizing behavior problems with the level of intelligence in adolescents. The subjects of this study were 150 adolescents aged I3-18 years in Bandung. Data was collected using the Child Behavior Checklist (CBCL) and Standard Progressive Matrices (SPM). The results showed the problem of internalizing behavior is negatively correlated with intelligence $(r=0.169, p=$ 0.01 ), which means that adolescents with a high level of intelligence, were found to show little problem of internalizing behavior. Conversely, adolescents with low intelligence, were found to show a lot of internalizing behavior problems. Adolescent externalization behavior problems do not have a certain correlation with the level of intelligence.
\end{abstract}

*Alamat korespondensi:

[Jl. Raya Bandung Sumedang No.KM 2I, Hegarmanah, Kec. Jatinangor, Kabupaten Sumedang, Jawa Barat 45363] [ekafauziyya@gmail.com] 


\section{Pendahuluan}

Masa remaja adalah masa perkembangan yang pesat dalam kemampuan kognitif dan sosial karena daerah otak yang terkait dengan kemampuan ini (seperti korteks prefrontal, daerah limbik) masih menuju kematangan (Blakemore \& Choudhury, 2006; Choudhury, Blakemore, \& Charman, 2006; Spear, 2000). Masa remaja juga merupakan masa peralihan dari masa anak-anak menuju kedewasaan. Pada masa ini remaja mengalami banyak perubahan pada dirinya dan mulai menampilkan perilaku-perilaku baru (Steinberg, 2002). Perubahan-perubahan tersebut meliputi perubahan fisik, psikis, dan sosial yang menyebabkan remaja mengalami pergolakan emosional sehingga masa remaja disebut masa storm dan stress (Hurlock, 2008). Selama masa remaja ini, cenderung muncul kesulitan atau permasalahan - permasalahan terkait perilaku karena mekanisme kontrol perilaku secara neurobiologis belum matang atau adanya peningkatan afiliasi pada kelompok teman sebaya yang juga memiliki masalah perilaku (Racz, Sarah Jensen; Putnick, Diane L; Suwalsky, Joan; Hendricks, Charlene; Bornstein, 2017).

Perubahan-perubahan yang terjadi pada remaja juga tidak lepas dari perkembangan aspek kognitif remaja. Menurut Santrock (2007), perkembangan kemampuan berpikir remaja masuk pada tahap operasional formal, yaitu pada tahap awal perkembangan berpikirnya, remaja mengalami peningkatan kemampuan untuk berpikir menggunakan hipotesis yaitu remaja mampu berpikir bebas mengenai kemungkinan-kemungkinan tanpa batas. Walaupun begitu cara berpikirnya masih sangat subjektif dan idealis. Sementara cara berpikir operasional tahap akhir yaitu remaja mengembangkan keseimbangan intelektual dengan mulai menguji hasil penalarannya pada realitas.

Kemampuan berpikir operasional formal memiliki implikasi emosional pada remaja (Papalia, 2009). Santrock (2007) menjelaskan kompetensi emosional yang dikembangkan pada masa remaja antara lain menyadari bahwa ekspresi emosi memainkan peranan penting dalam relasi; secara adaptif mengatasi emosi-emosi negatif dengan menggunakan strategi regulasi-diri yang dapat menurunkan intensitas dan lamanya kondisi-kondisi emosional; memahami bahwa kondisi emosional di dalam diri tidak berkaitan dengan ekspresi keluar; memahami bagaimana perilaku emosionalnya dapat mempengaruhi orang lain; belajar mempertimbangkan cara-cara menampilkan dirinya; menyadari kondisi emosional diri sendiri, serta memahami emosi-emosi orang lain.

Tidak sedikit remaja yang kesulitan dalam mengatasi permasalahan-permasalahan pada masa remaja ini karena tidak adanya pendampingan atau pemahaman mengenai karakteristik remaja dari lingkungannya. Kesulitan dalam fungsi sosial dan masalah perilaku pada remaja sering dikaitkan dengan beberapa kelemahan dalam fungsi kognitif, misalnya remaja yang memiliki masalah perilaku juga memiliki tingkat kecerdasan yang rendah, penalaran verbal yang buruk, kesulitan dalam memproses persepsi dan spasial, serta kesulitan dalam kemampuan bahasanya (Racz et al, 2017).

Masalah perilaku juga tidak memiliki etiologi yang tunggal melainkan kombinasi dari berbagai masalah, misalnya lingkungan yang berisiko tinggi, status sosial ekonomi yang rendah, penolakan teman sebaya, keraguan diri yang ekstrim dan perbedaan biologis atau biokimia (Easterbrooks, Davidson, \& Chazan, 1993). Misalnya siswa di sekolah yang dipisahkan berdasarkan tingkat kecerdasan ditemukan memiliki perbedaan perilaku yang signifikan karena pengaruh perasaan penolakan oleh teman sebaya dan guru (Roberts dan Zubrick, 1992).

Masalah perilaku dapat diklasifikasikan sebagai masalah perilaku eksternalisasi dan internalisasi (Achenbach, 1991). Perilaku eksternalisasi yaitu perilaku yang bermasalah secara sosial, remaja bertindak negatif terhadap lingkungan sekitarnya, perilaku ini ditunjukkan dengan ketidakpatuhan, melanggar aturan, kemarahan, agresi verbal, kenakalan, penolakan atau perlawanan remaja terhadap lingkungan sosialnya. Perilaku seperti ini bermasalah bagi masyarakat karena memberikan efek buruk dan negatif yang bersifat langsung dan berjangka panjang bagi individu itu sendiri maupun orang-orang di sekitarnya. Penelitian longitudinal menunjukkan perilaku eksternalisasi 
remaja adalah faktor risiko utama dari berbagai perilaku negatif seperti kenakalan remaja, kejahatan dan kekerasan di masa depan (Liu, 2004).

Kemudian perilaku eksternalisasi juga mengakibatkan penurunan pada pencapaian pendidikan dan pekerjaan di masa dewasa (Tanner, Davies dan Grady, 1999). Anak-anak dengan masalah eksternalisasi yang tinggi lebih sulit untuk diajar daripada teman-teman sebayanya karena mereka tidak tertarik untuk belajar, kesulitan mengikuti arahan, dan sering tidak memiliki kontrol diri (Papachristou \& Flouri, 2019). Anak-anak yang menunjukkan pola perilaku eksternalisasi di awal perkembangannya, menunjukkan kesulitan perilaku berkelanjutan di seluruh perkembangan seperti prestasi akademik yang buruk dan penolakan sosial (Moffitt, 1993). Prestasi yang rendah dapat bertindak sebagai mediator dalam hubungan antara kenakalan remaja dan depresi pada dewasa awal (Siennick, 2007).

Sementara itu, perilaku internalisasi merupakan masalah perilaku yang diarahkan pada diri sendiri dan dikendalikan secara berlebihan, sehingga mempengaruhi keadaan psikologis seseorang, misalnya penarikan diri dari sosial, keluhan somatik, kesepian, kecemasan, dan depresi (Madigan, Atkinson, Laurin, Benoit, 20I2). Masalah perilaku internalisasi ini bersifat terselubung, sehingga mereka yang mengalaminya sering tidak diperhatikan. Walaupun begitu, gejala internalisasi merupakan masalah yang luas dikalangan remaja. Diperkirakan sekitar $15-35 \%$ individu mengalami gejala depresi selama remaja (Hamza dan Willoughby, 20II). Kemudian pada masa remaja tingkat kecemasan dan depresi sangat tinggi, dengan persentase masing-masing $12,6 \%$ dan $32,4 \%$ (Kessler et al., 20I2).

Selain itu masalah internalisasi merupakan faktor risiko dari berbagai hasil negatif, seperti tingkat depresi yang tinggi pada remaja dikaitkan dengan penyesuaian yang kurang positif pada masa dewasa, tingkat harga diri dan efikasi diri yang rendah, keterlibatan pada perilaku eksternalisasi, prestasi akademik yang buruk, serta resiko besar untuk melakukan percobaan bunuh diri selama masa remaja (Georgiou \& Symeou, 20I8). Gejala depresi secara longitudinal memprediksi perilaku bunuh diri pada remaja, terutama pada remaja perempuan (Piqueras et al., 2019). Individu yang menunjukkan kecerdasan rendah kesulitan membuat respons yang mengarah pada kesuksesan, pada akhirnya individu tersebut mengembangkan kecemasan (Coplan et al., 2012). Anak yang menunjukkan perilaku internalisasi juga mempengaruhi kemampuannya untuk belajar, misalnya anak dengan perilaku internalisasi memiliki kinerja kecerdasan yang lebih buruk dibandingkan dengan anak-anak yang tidak memiliki permasalahan perilaku internalisasi (Racs et al, 20I7).

Penelitian sebelumnya juga menunjukkan perbedaan gender sehubungan dengan tekanan psikologis terkait masalah perilaku ini. Anak laki-laki ditemukan lebih banyak mengembangkan masalah perilaku eksternalisasi seperti perilaku berpura-pura, penyalahgunaan narkoba, dan meminum alkohol, sedangkan anak perempuan lebih banyak mengembangkan masalah-masalah emosional seperti kemurungan, kegelisahan, depresi dan keinginan untuk bunuh diri (Offer \& Schonert-Reichl, 1992).

Perilaku eksternalisasi dan internalisasi pada remaja dapat diidentifikasi lebih lanjut melalui Child Behavior Checklist $(\mathrm{CBCL})$ yang merupakan suatu daftar perilaku untuk menggambarkan perilaku klinis pada anak dan remaja. CBCL diisi oleh orangtua, pengasuh, ataupun guru yang berinteraksi dengan anak atau remaja dalam rentang usia $6-18$ tahun. CBCL dikembangkan Achenbach (1991) ini, memuat daftar perilaku yang dibagi menjadi kelompok perilaku internalisasi dan eksternalisasi, serta pernyataan mengenai perilaku lainnya yang diisi oleh pengasuh apabila tidak tercantum pada daftar perilaku yang ada. CBCL mengidentifikasikan perilaku internalisasi menjadi tiga bentuk masalah perilaku yaitu anxious, withdrawn, somatic complaints, dan perilaku eksternalisasi menjadi dua bentuk masalah perilaku yaitu rule breaking behavior dan aggressive behavior.

Perkembangan remaja dengan segala transisi yang telah dijelaskan di atas, membuat peneliti tertarik menelusuri permasalahan mengenai perilaku internalisasi dan eksternalisasi pada masa remaja ini. 
Berdesarkan literatur dan penelitian mengenai perkembangan remaja yang telah dipaparkan, peneliti menyimpulkan pada satu sisi remaja mengalami perkembangan kognisi yang pesat dibandingkan masa anak-anak seperti mereka mulai dapat membuat hipotesis-hipotesis dan berpikir secara abstrak, namun disisi lain mereka juga sedang mengalami gejolak emosi. Perkembangan kognisi dan emosi ini saling berkaitan dalam tampilan perilaku yang mereka tunjukkan di lingkungan.

Oleh karena itu peneliti tertarik untuk meneliti hubungan antara masalah perilaku dengan perkembangan kognisi remaja ini. Perkembangan kognitif pada remaja peneliti identifikasi melalui tingkat kecerdasan. Tingkat kecerdasan (IQ) menunjukkan hubungan spesifik pada gejala internalisasi dan eksternalisasi (Blanken et al., 2017). Permasalahan perilaku diidentifikasi melalui CBCL dari Achenbach. Peneliti berharap hasil penelitian ini nantinya dapat dijadikan gambaran mengenai hubungan masalah perilaku internalisasi dan eksternalisasi remaja dengan kecerdasan yang mana dapat dijadikan acuan untuk penanganan masalah perilaku remaja di rumah maupun di sekolah sesuai potensi kecerdasan remaja tersebut

\section{Metode}

Desain penelitian yang digunakan adalah kuantitatif dengan pendekatan non eksperimen. Sampel penelitian adalah remaja berusia 13 - 18 tahun di Kota Bandung sebanyak 150 partisipan. Sampel dikumpulkan secara random dari SMP dan SMA di Bandung. Sebanyak 61\% remaja perempuan, dan $39 \%$ remaja laki-laki berpartisipasi dalam penelitian ini. Pengambilan data kecerdasan dilakukan melalui alat tes Standard Progressive Matrices (SPM) dan data masalah perilaku melalui Child behavior Checklist (CBCL) yang dikembangkan Achenbach (199I). Data kecerdasan dikumpulkan secara langsung dengan mendatangi tiap sekolah. SPM merupakan alat tes kecerdasan yang dikembangkan oleh Raven pada tahun 1938, memiliki validitas yang baik dalam mengukur kemampuan kognitif pada tiap budaya, etnis, social ekonomi yang berbeda di berbagai Negara (Raven, 2000). SPM berisi 60 gambar sebagai persoalan. Gambar tersebut dikelompokkan menjadi lima kelompok yang disebut set A, B, C, D, dan E, masing-masing terdiri dari 12 item. Setiap item terdiri dari gambar dan pola-pola tertentu. Untuk set A dan B disediakan enam gambar sebagai pilihan jawaban, sedangkan untuk set C, D, E disediakan delapan pilihan jawaban. Partisipan diminta untuk memilih salah satu jawaban yang dirasa tepat sesuai dengan persoalan.

Setelah data kecerdasan terkumpul, peneliti memberikan kuesioner untuk orangtua pada anak untuk diisi di rumah. Orang tua partisipan diminta untuk mengisi Child Behavior Checklist (CBCL) yang terdiri dari $1 / 2$ pernyataan yang menggambarkan masalah perilaku internalisasi dan eksternalisasi pada anak berusia 6 - 18 tahun. Orangtua diberikan pilihan angka dari $0-2$ untuk menentukan kesesuaian pernyataan perilaku-perilaku tersebut dengan anak mereka. $\mathrm{CBCL}$ kemudian dikumpulkan kembali ke peneliti setelah diisi oleh orangtua atau wali masing-masing. Keterlibatan partisipan dalam penelitian sudah melalui persetujuan partisipan, guru, dan orangtua.

Data dianalisis menggunakan SPSS versi 20. Pengujian dilakukan menggunakan analisis korelasi Rank Spearman untuk melihat hubungan masalah perilaku eksternalisasi dan internalisasi dengan golongan kecerdasan. Menurut Sugiyono (2012), korelasi Rank Spearman digunakan untuk mencari hubungan atau untuk menguji signifikasi hipotesis asosiatif bila masing - masing variabel yang dihubungkan berbentuk ordinal, dan sumber data antar variabel tidak harus sama. Pada penelitian ini data masalah perilaku dan golongan kecerdasan berbentuk ordinal. Kemudian peneliti juga melakukan Uji Analysis of varians (Anova), menguji ada tidaknya pengaruh dari variabel bebas secara keseluruhan terhadap variabel dependen (Sugiyono, 20I2). Pada penelitian ini uji anova digunakan untuk melihat perbedaan masalah perilaku internalisasi dan eksternalisasi antara remaja laki-laki dan perempuan. 


\section{Hasil}

Peneliti memperoleh 150 partisipan, sebanyak $61 \%$ partisipannya adalah remaja perempuan, dan $39 \%$ remaja laki-laki. Partisipan terdiri dari pelajar SMP dan SMA berusia $13-18$ tahun dari 6 sekolah di Kota Bandung. Profil partisipan dapat dilihat pada tabel I.

\section{Tabel I}

\section{Profil Partisipan}

\begin{tabular}{lcc}
\hline Demografi & Frekuensi & Persentase \\
\hline Jenis Kelamin Partisipan & & \\
Perempuan & 92 & $61 \%$ \\
Laki-laki & 58 & $39 \%$ \\
Usia Partisipan & & \\
I3 tahun & 51 & $34 \%$ \\
I4 tahun & 36 & $24 \%$ \\
I5 tahun & 29 & $19 \%$ \\
I6 tahun & 11 & $7 \%$ \\
I7 tahun & 8 & $5 \%$ \\
18 tahun & 15 & $10 \%$ \\
\hline
\end{tabular}

Kemudian berdasarkan tingkat kecerdasannya, sebagian besar partisipan berada pada tingkat kecerdasan golongan II (di atas rata-rata) dengan persentase 55\%, selanjutnya mengikuti $31 \%$ berada pada golongan III (rata-rata), I2\% golongan I (superior), dan 3\% golongan IV (di bawah rata-rata).

\section{Tabel 2}

\section{Perolahen Tingkat Kecerdasan}

\begin{tabular}{lcc}
\hline Tingkat Kecerdasan & Frekuensi & Persentase \\
\hline Golongan I (superior) & 18 & $12 \%$ \\
Golongan II (di atas rata-rata) & 82 & $55 \%$ \\
Golongan III (rata-rata) & 46 & $31 \%$ \\
Golongan IV (di bawah rata-rata) & 4 & $3 \%$ \\
\hline
\end{tabular}

Hubungan perilaku internalisasi dan eksternalizing dengan bentuk-bentuk perilakunya

$\mathrm{CBCL}$ mengidentifikasikan perilaku internalisasi menjadi tiga bentuk yaitu anxious, withdrawn, somatic complaints, dan perilaku eksternalisasi menjadi dua bentuk yaitu rule breaking behavior dan aggressive behavior. Baik perilaku masing-masing perilaku internalisasi maupun eksternalisasi saling berkorelasi satu sama lain seperti yang ditunjukkan pada tabel 3 .

\section{Tabel 3}

Korelasi antar masalah perilaku

\begin{tabular}{lccccc}
\hline Kategori & Anxious & Withdrawn & $\begin{array}{l}\text { Somatic } \\
\text { Complaints }\end{array}$ & $\begin{array}{l}\text { Rule-Breaking } \\
\text { Behavior }\end{array}$ & $\begin{array}{l}\text { Aggressive } \\
\text { Behavior }\end{array}$ \\
\hline Internalisasi & $.907^{* *}$ & $.839 * *$ & $.781^{* *}$ & $.651^{* *}$ & $.773^{* *}$ \\
Eksternalisasi & $.782^{* *}$ & $.627^{* *}$ & $.612^{* *}$ & $.840^{* *}$ & $.957^{* *}$ \\
\hline
\end{tabular}

$\mathrm{p}<0.01$

Berdasarkan tabel 3 dapat dilihat bahwa masalah perilaku internalisasi dan eksternalisasi berkorelasi positif dengan setiap bentuk-bentuk masalah perilakunya. Internalisasi berkorelasi positif dengan anxious $(r=0.907)$, withdrawn $(r=0.839)$, somatic complaints $(r=0.78 \mathrm{I})$, rule breaking behavior $(r=0.65 \mathrm{I})$, dan aggressive behavior $(r=0.773)$. Eksternalisasi juga berkorelasi 
positif dengan anxious $(r=0.782)$, withdrawn $(r=0.627)$, somatic complaints $(r=0.612)$, rule breaking behavior $(r=0.840)$, dan aggressive behavior $(r=0.957)$. Hal ini sesuai dengan pendapat Eisenberg (200l) yang menyatakan gejala internalisasi dan eksternalisasi cenderung berhubungan positif. Anak-anak yang memiliki gejala eksternalisasi bisa juga mengalami gejala internalisasi seperti kesedihan, ketakutan dan kecemasan walaupun tingkatannya tidak sebesar anak yang mengalami masalah perilaku internalisasi (Eisenberg, 200I). Anak-anak yang agresif juga mungkin mengalami kecemasan dan, sebaliknya, anak-anak yang depresi juga menunjukkan perilaku bermasalah di lingkungannya (Liu, 2004).

Hubungan masalah perilaku internalisasi dan eksternalizing dengan kecerdasan

Pengujian korelasi antara masalah perilaku internalisasi dan eksternalisasi dengan kecerdasan pada remaja di Kota Bandung, menghasilkan hanya perilaku internalisasi yang berkorelasi dengan kecerdasan dengan arah korelasi negatif $(r=0.169)$. Sementara masalah perilaku eksternalisasi tidak memiliki korelasi dengan kecerdasan, hasil korelasinya dapat dilihat pada tabel 4 berikut ini :

\section{Tabel 4}

\section{Korelasi masalah perilaku internalisasi dan eksternalisasi dengan kecerdasan}

\begin{tabular}{ll} 
Perilaku & IQ \\
\hline Internalisasi & $-.169^{*}$ \\
Anxious & -.151 \\
Withdrawn & -.112 \\
Somatic Complaints & $-.219^{* *}$ \\
Eksternalisasi & -.147 \\
Rule-Breaking Behavior & $-.165^{*}$ \\
Aggressive Behavior & -.117 \\
\hline
\end{tabular}

Pada perilaku internalisasi, kecerdasan berkorelasi negatif dengan somatic complaints $(r=0.219)$. $\mathrm{Hal}$ ini berarti, semakin tinggi tingkat kecerdasan, maka semakin sedikit keluhan somatik yang ditunjukkan. Sebaliknya semakin rendah tingkat kecerdasan maka semakin banyak keluhan somatik yang ditunjukkan. Sementara pada perilaku eksternalisasi, meskipun secara keseluruhan tidak terdapat hubungan tertentu pada masalah perilaku eksternalisasi remaja dengan kecerdasannya, namun jika dilihat berdasarkan masalah perilaku yang terdapat dalam bagian eksternalisasi, kecerdasan berkorelasi dengan rule breaking behavior $(r=0.165)$. Korelasi rule breaking behavior dan kecerdasan menghasilkan hubungan semakin tinggi tingkat kecerdasan, maka semakin sedikit perilaku tidak mematuhi aturan. Sebaliknya semakin rendah tingkat kecerdasan, maka semakin banyak pula perilaku tidak mematuhi aturan yang ditunjukkan remaja.

Pengaruh perbedaan jenis kelamin terhadap masalah perilaku internalisasi dan eksternalisasi

Untuk melihat perbandingan perilaku internalisasi dan eksternalisasi antara remaja perempuan dan laki-laki dilakukan uji anova. Hasilnya diperoleh tidak terdapat perbedaan antara perempuan dan laki-laki berkaitan dengan perilaku internalisasi $(F(I, I 48)=2,96 ; p>0.05)$. Begitu pula pada perilaku eksternalisasi, jenis kelamin juga tidak memiliki pengaruh terhadap masalah perilaku eksternalisasi pada remaja di Kota Bandung $(F(I, I 48)=0.09 ; p>0.05)$.

\section{Pembahasan}

Pada penelitian ini, hanya masalah perilaku internalisasi yang berkorelasi dengan tingkat kecerdasan $(r=0.169)$. Arah hubungan negatif pada korelasi perilaku internalisasi dan kecerdasan menunjukkan semakin tinggi atau banyaknya perilaku internalisasi yang ditampilkan remaja maka 
semakin rendah tingkat kecerdasannya. Begitu pula semakin rendah atau sedikit perilaku internalisasi yang ditampilkan maka semakin tinggi tingkat kecerdasannya. Hasil ini menunjukkan remaja yang memiliki potensi kecerdasan yang cukup baik, lebih sedikit memiliki masalah perilaku internalisasi. Sementara remaja yang memiliki potensi kecerdasan yang cukup rendah, kemungkinan menampilkan banyak masalah perilaku internalisasi. Hal ini sesuai dengan yang diungkapkan Papachristou (2019) bahwa anak-anak dengan kemampuan kognitif rendah lebih cenderung menunjukkan kesulitan kesehatan mental seperti gejala internalisasi dan eksternalisasi dibandingkan dengan mereka yang tidak memiliki gejala permasalahan perilaku.

Garnefski et al (2005) mengungkapkan faktor kognitif memiliki pengaruh dalam masalah perilaku pada remaja, terutama terkait strategi regulasi emosi secara kognitif yang digunakan remaja dalam menangani informasi-informasi atau pengalaman negatif yang mereka hadapi dan dapat membangkitkan emosi. Menurut perkembangannya, remaja mengalami transisi kognitif yaitu kemampuan untuk mempertimbangkan hal-hal yang abstrak dan bersifat hipotesis mulai berkembang dan perkembangan kognitif itu berguna untuk memantau aktivitas mereka selama proses berpikir (Steinberg, 2002).

Proses kognitif ini penting dalam mengelola atau mengatur emosi dan perasaan, mengendalikan emosi selama mengalami pengalaman yang mengancam atau menekannya. Perbedaan kemampuan kognitif tiap orang yang dapat diidentifikasi melalui potensi kecerdasan bisa mempengaruhi cara setiap remaja dalam mengatur emosi dan menanggapi pengalaman hidup yang menekan (Garnefski et al., 2005). Pendapat Garnefski mendukung hasil penelitian ini, yaitu remaja yang memiliki tingkat kecerdasan yang cukup tinggi, menampilkan sedikit masalah perilaku internalisasi. Remaja yang memiliki tingkat kecerdasan yang cukup tinggi bisa dikatakan mengembangkan strategi regulasi emosi yang cukup baik dalam menangani informasi atau pengalaman yang mengancam di lingkungannya, sehingga masalah perilaku internalisasi tidak banyak ditampilkan. Sementara remaja yang memiliki tingkat kecerdasan yang cukup rendah, belum mengembangkan strategi yang tepat dalam meregulasi emosinya, sehingga banyak memunculkan masalah perilaku internalisasi.

Begitu pula Graber, Julia dan Sontag (2009) mengungkapkan masalah internalisasi merupakan indikasi kesulitan dalam mengatur keterampilan regulasi emosi. Regulasi emosi didefinisikan sebagai proses ekstrinsik dan intrinsik yang bertanggung jawab untuk memantau, mengevaluasi, dan memodifikasi reaksi emosional. Keterampilan pengaturan emosi melibatkan kesulitan dalam mengatur emosi dan penggunaan strategi regulasi emosi adaptif atau maladaptif yang spesifik (te Brinke et al., 2018). Selain itu Papachristou (2019) juga mengungkapkan anak-anak dengan permasalahan internalisasi memiliki sedikit peluang untuk memperkuat kemampuan kognitifnya. $\mathrm{Hal}$ ini karena adanya perasaan cemas dan mereka cenderung lebih sedikit mengambil resiko, sehingga mempengaruhi aktivitas belajarnya secara negatif.

Disisi lain, tidak terdapat hubungan antara perilaku eksternalisasi dengan tingkat kecerdasan. Hal ini bisa dikatakan tingkat kecerdasan bukan merupakan salah satu faktor yang kuat dalam keterlibatan remaja pada perilaku eksternalisasi. Terdapat faktor-faktor lainnya yang kemungkinan memiliki peran yang lebih besar dalam hal tersebut. Georgiou (2018) mengungkapkan pada penelitian perilaku eksternalisasi dan internalisasi, faktor penting yang perlu dipertimbangkan adalah keterlibatan orang tua. Keterlibatan orang tua merupakan bagian integral dari perilaku dan kesejahteraan psikososial anak. Keterlibatan orang tua berkaitan dengan penyesuaian psikologis positif, kebahagiaan, dan lebih sedikit terlibat dalam perilaku merundung atau perilaku antisosial (Flouri dan Buchanan, 2000).

Dukungan orang tua yang rendah terkait dengan hasil psikologis yang buruk, dimulai pada masa kanak-kanak dan dapat terus mempengaruhi anak-anak di kemudian hari dalam kehidupan mereka (Roelofs et al. 2006). Kurangnya kehangatan dan proteksi orang tua juga meningkatkan risiko anak terlibat dalam masalah perilaku internalisasi dan eksternalisasi (Muris et al. 2003). Sebagai contoh, 
kurangnya kehangatan orang tua, keterlibatan, dan perilaku pengasuhan terkait dengan tingkat agresi dan masalah perilaku eksternalisasi yang ditunjukkan oleh anak-anak (Stormshak et al. 2000).

Konflik orang tua dan anak juga sering ditemukan sebagai prediktor gejala perilaku eksternalisasi pada remaja (Georgiou \& Symeou, 2018). Eichelsheim et al. (2010) menemukan bahwa kualitas negatif dari hubungan orang tua-remaja yang ditandai dengan perselisihan berulang dan orang tua yang negatif, sangat berkaitan dengan tingkat agresi pada remaja. Pola interaksi negatif dan koersif pada hubungan orang tua dan remaja menimbulkan agresi interpersonal pada remaja. Hal ini mempengaruhi tampilan perilaku remaja pada lingkungan sosialnya.

Selain itu, Liu (2004) menjelaskan faktor risiko biologis dan psikososial juga dapat menyebabkan permasalahan perilaku eksternalisasi pada anak. Faktor risiko biologis berkaitan dengan perkembangan selama periode prenatal dan perinatal, termasuk faktor genetik dan patofisiologis ibu yang dapat menghambat pertumbuhan dan perkembangan janin. Contoh dari faktor-faktor tersebut antara lain malnutrisi ibu, penyakit selama kehamilan, merokok, menggunakan obatobatan dan alkohol selama kehamilan, kecenderungan genetik untuk perilaku eksternalisasi dari ibu dan ayah, serta komplikasi kelahiran. Faktor yang mempengaruhi perkembangan saraf janin, seperti sindrom alkohol janin dapat merusak daerah otak (corpus callosum). Sebagai contoh, komplikasi persalinan dapat secara langsung melukai sistem saraf pusat bayi baru lahir. Merokok selama kehamilan juga mempengaruhi struktur dalam sistem saraf pusat sehingga mengarah pada peningkatan perilaku eksternalisasi pada keturunannya.

Kemudian faktor psikososial merupakan faktor risiko selama anak usia dini yang bersifat psikologis dan sosial. Contohnya antara lain kemiskinan, stres psikososial yang tinggi, sikap negatif terhadap kehamilan, kehamilan remaja, dan faktor kejiwaan seperti penyalahgunaan narkoba atau alkohol. Etiologi dari beberapa faktor risiko cukup kompleks dan kemungkinan kedua faktor genetik dan lingkungan dapat berkontribusi terhadap faktor risiko sosial atau faktor risiko sosial berkontribusi terhadap faktor risiko biologis. Sebagai contoh, penyalahgunaan narkoba dan alkohol umumnya dipandang sebagai masalah perilaku sosial, tetapi juga kemungkinan individu yang menyalahgunakan narkoba atau alkohol memiliki sifat genetika atau biologis terhadap perilaku tersebut (Liu, 2004). Werner (1989) juga mengungkapkan hasil perkembangan dari semua faktor risiko biologis tergantung pada kualitas lingkungan tempat anak dibesarkan. Misalnya, anak-anak yang mengalami komplikasi prenatal dan perinatal kemungkinan besar menunjukkan gangguan psikologis pada usia 10 dan 18 tahun ketika komplikasi ini dikombinasikan dengan kemiskinan, perselisihan keluarga, dan kondisi buruk lainnya.

Kemudian White \& Renk (20II) juga menjelaskan faktor lainnya yang mempengaruhi perilaku eksternalisasi remaja yaitu faktor ekologi. Faktor ekologi memandang individu terlibat dalam berbagai sistem, anak-anak mengalami pengaruh langsung dan tidak langsung dari keluarga mereka (misalnya, orang tua dan peran keluarga), komunitas (misalnya, sekolah, teman sebaya, lembaga lain), serta budaya dan masyarakat (misalnya, nilai-nilai, sikap, etnis). Regulasi emosi anak-anak dipelajari dan diperkuat oleh keluarga mereka. Anak-anak dan remaja dipengaruhi secara langsung oleh keluarga mereka dan secara tidak langsung dipengaruhi oleh jejaring sosial orang tua mereka. Berdasarkan faktor ekologi ini, lingkungan sosial berperan dalam pengembangan masalah perilaku eksternalisasi remaja.

\section{Kesimpulan}

Berdasarkan hasil penelitian, masalah perilaku internalisasi memiliki korelasi negatif dengan kecerdasan, yang berarti remaja dengan tingkat kecerdasan tinggi, menunjukkan sedikit masalah perilaku internalisasi. Hal ini bisa disebabkan remaja dengan kecerdasan yang tinggi mulai mengembangkan strategi regulasi emosi yang tepat dalam menghadapi masalah atau tekanan di 
lingkungan menggunakan potensi kecerdasan yang mereka miliki (te Brinke et al., 2018). Sebaliknya, remaja dengan tingkat kecerdasan rendah, ditemukan banyak menunjukkan masalah perilaku internalisasi. Potensi kecerdasan yang rendah, dapat menjadi penghambat bagi remaja untuk mengembangkan strategi regulasi emosi yang sesuai keadaannya, sehingga dalam menghadapi masalah atau tekanan dari lingkungan, mereka lebih banyak menampilkan perilaku-perilaku internalisasi (Garnefski, 2005; Papachristou, 2019).

Disisi lain, masalah perilaku eksternalisasi remaja tidak memiliki hubungan tertentu dengan tingkat kecerdasannya. Hal ini bisa disebabkan faktor-faktor lain yang kemungkinan lebih mendukung terbentuknya masalah perilaku eksternalisasi selain kecerdasan remaja. Faktor-faktor tersebut antara lain keterlibatan orangtua, faktor biologis yang berhubungan dengan perkembangan saraf dan hormon, faktor psikososial, dan juga faktor ekologi terkait lingkungan, budaya dan tempat remaja tersebut menetap selama perjalanan hidupnya (Georgiou \& Symeou, 2018; Liu, 2004; White \& Renk, 20II).

Hasil penelitian ini dapat menjadi bahan referensi bagi pihak-pihak yang tertarik pada psikologi perkembangan, terutama bagi para peneliti selanjutnya yang berminat meneliti lebih lanjut mengenai masalah perilaku internalisasi dan eksternalisasi pada remaja. Keterbatasan penelitian yaitu partisipan penelitian ini didominasi oleh perempuan, sehingga sulit dilakukan analisis perbedaan tiap masalah perilaku berdasarkan jenis kelamin. Selain itu, peneliti selanjutnya juga dapat memperbanyak jumlah partisipan dengan berbagai variasi usia, serta menambahkan kriteria seperti melibatkan partisipan dari remaja normal dan remaja yang sudah didiagnosa mengalami masalah psikologis atau perilaku tertentu, sehingga dapat dilihat perbandingan antar keduanya.

\section{REFERENSI}

Achenbach, T. M. (1991). Manual for the child behavior checklist and 1991 profile. Burlington: Department of Psychiatry, University of Vermont.

Blakemore SJ, Choudhury S. (2006). Development of the adolescent brain: Implications for executive function and social cognition. Journal of Child Psychology and Psychiatry. 47:296-312. DOI: I0.IIII/j. I469-76I0.2006.016 I I.x [PubMed: 1649226I] Blandon

Blanken, L. M. E., White, T., Mous, S. E., Basten, M., Muetzel, R. L., Jaddoe, V. W. V., Wals, M., van der Ende, J., Verhulst, F. C., \& Tiemeier, H. (20I7). Cognitive functioning in children with internalising, externalising and dysregulation problems: a population-based study. European Child and Adolescent Psychiatry, 26(4), 445-456. https://doi.org/I0.1007/s00787-016-0903-9

Choudhury S, Blakemore SJ, Charman T. (2006). Social cognitive development during adolescence. Social Cognitive and Affective Neuroscience; 1:165-174. DOI: 10.1093/scan/ns1024 [PubMed: I8985I03

Coplan, J. D., Hodulik, S., Mathew, S. J., Mao, X., Hof, P. R., Gorman, J. M., \& Shungu, D. C. (2012). The relationship between intelligence and anxiety: An association with subcortical white matter metabolism. Frontiers in Evolutionary Neuroscience, 3(FEB), I-7. https://doi.org/l0.3389/fnevo.20II.00008

Easterbrooks, M. A., Davidson, C. E., \& Chazan, R. (1993). Psychosocial risk, attachment, and behavior problems among school-aged children. Development and Psychopathology, 5 (3), 389-402.

Eichelsheim, V. I., Buist, K. L., Deković, M., Wissink, I. B., Frijns, T., van Lier, P. A. C., Koot, H. M., \& Meeus, W. H. J. (2010). Associations between the parent-adolescent rela- tionship, aggression and delinquency in different ethnic groups: A replication across two Dutch samples. Social Psychiatry Epidemiology. 45:293-300

Flouri, E., \& Buchanan, A. (2000). What predicts good relationships with parents in ado- lescence and partners in adult life: Findings from the 1958 British birth cohort. Journal of Family Psychology. 16:186-198

Garnefski, N., Kraaij, V., \& van Etten, M. (2005). Specificity of relations between adolescents' 
cognitive emotion regulation strategies and Internalizing and Externalizing psychopathology. Journal of Adolescence, 28(5), 619-63I. https://doi.org/10.1016/j.adolescence.2004.12.009

Georgiou, S. N., \& Symeou, M. (2018). Parenting Practices and the Development of Internalizing/ Externalizing Problems in Adolescence. Parenting - Empirical Advances and Intervention Resources. https://doi.org//0.5772/66985

Graber, Julia; Sontag, L. (2009). Internalizing Problem During Adolescence. 642-682.

Kessler, R., Petukhova, M., Sampson, N., Zaslavsky, A., \& Wittchen, H. (20I2). Twelve-month and lifetime prevalence and lifetime morbid risk of anxiety and mood disorders in the United States. International Journal of Methods in Psychiatric Research, 17 Suppl I, S78-S82. https://doi.org/10.1002/mpr

Liu, J. (2004). Childhood externalizing behavior: theory and implications. Journal of Child and Adolescent Psychiatric Nursing: Official Publication of the Association of Child and Adolescent Psychiatric Nurses, Inc, I7(3), 93-103. http://www.ncbi.nlm.nih.gov/pubmed/I5535385

Madigan, S., Atkinson, L., Laurin, K., \& Benoit, D. (2012). Attachment and internalizing behavior in early childhood: A meta-analysis. Developmental Psychology. 49(4):672-689

Moffitt TE.(1993). Adolescence-limited and life-course-persistent antisocial behavior-A developmental taxonomy. Psychological Review, I00:674-70I. [PubMed: 8255953]

Muris, P., Meesters, C., \& van den Burg, S. (2003). Internalizing and externalizing problems as correlates of self-reported attachment style and perceived parental rearing in normal adolescents. Journal of Child and Family Studies, 12, I7|-|83.

Offer, D. and Schonert-Reichl, K. A. (1992) Debunking three myths of adolescence: findings from recent research. Journal of the American Academy of Child Adolescent Psychiatry, 3I, $1003-1014$.

Papachristou, E., \& Flouri, E. (2019). The codevelopment of internalizing symptoms, externalizing symptoms, and cognitive ability across childhood and adolescence. Development and Psychopathology, I-15. https://doi.org/I0.1017/S095457941900I330

Papalia, D. E., Olds, S. W., Feldman, R. D. (2009). Human Development: Psikologi Perkembangan (Edisi Kesembilan). Alih bahasa oleh A.K. Anwar. Jakarta: Kencana

Piqueras, J. A., Soto-Sanz, V., Rodríguez-Marín, J., \& García-Oliva, C. (2019). What is the role of internalizing and externalizing symptoms in adolescent suicide behaviors? International Journal of Environmental Research and Public Health, I6(14). https://doi.org/ I0.3390/ijerph I6I425 I I

Racz, Sarah Jensen; Putnick, Diane L; Suwalsky, Joan; Hendricks, Charlene; Bornstein, M. (2017). Cognitive Abilities, Social Adaptation, and Externalizing Behavior Problems in Childhood and Adolescence: Specific Cascade Effects across Development. 46(8), 1688-170I. https://doi.org/I0.1007/s 10964-016-0602-3.Cognitive

Raven, J. (2000). The Raven's Progressive Matrices: Change and Stability over Culture and Time. Cognitive Psychology, 4 I (I), I-48. https://doi.org// 0. I006/cogp. 1999.0735

Roberts, C., \& Zubrick, S. (1992). Factors influencing the social status of children with mild academic disabilities in regular classrooms. Exceptional Children, 59 (3), 192- 202

Roelofs, J., Meesters, C., Ter Huurne, M., Bamelis, L., \& Muris, P. (2006). On the links between attachment style, parental rearing behavior, and internalizing and externalizing problems in non- clinical children. Journal of Child and Family Studies, 15, 33 I-344

Santrock, J. W. (2007). Adolescence. Jakarta: Erlangga

Siennick, S. E. (2007). The timing and mechanisms of the offending-depression link. Criminology. 45(3):70I-734

Spear LP. (2000). The adolescent brain and age-related behavioral manifestations. Neuroscience and Biobehavioral Review; 24:4I7-463. DOI: 10.1016/S0I49-7634(00)000I4-2

Steinberg, Lawrence. 2002. Adolescence. Sixth edition, New York: McGraw Hill. Inc. Adams

Stormshak, E. A., Bierman, K. L., McMahon, R. J., \& Lengua, L. J. (2000). Parenting practices and child disruptive behavior prob- lems in early elementary school. Journal of Clinical Child Psychology, 29, 17-29

Sugiyono. (20I2). Metode Penelitian Pendidikan: Pendekatan Kuantitatif, Kualitatif, dan R \& D. Bandung: Alfabeta.

Tanner, J., Davies, S., \& O"Grady, B. (1999). Whatever happened to yesterday's rebels? 
Longitudinal effects of teenage delinquency on education and occupational outcomes. Social Problems. 46(2):250-274

te Brinke, L. W., Schuiringa, H. D., Menting, A. T. A., Deković, M., \& de Castro, B. O. (2018). A cognitive versus behavioral approach to emotion regulation training for externalizing behavior problems in adolescence: Study protocol of a randomized controlled trial. BMC Psychology, 6(I), I-12. https://doi.org/I0.1 I86/s40359-0I8-026I-0

Werner, E. R. (1989). Vulnerability and resiliency: A longitudinal perspective. Children at risk: Assessment, longitudinal research, and intervention (pp. 158-172). Oxford, England: Walter de Gruyter

White, R., \& Renk, K. (20II). Externalizing Behavior Problems During Adolescence: An Ecological Perspective.Journal of Child and Family Studies, 2I(I),I58-17I. https://doi.org/I0.1007/s I082601 I-9459-y 